\title{
AZ ONLINE KERESKEDELEM TÉRHÓDÍTÁSA ÉS SZABÁLYOZÁSA
}

\section{The Expansion and Regulation of the Online Commerce}

\section{Szűcs Gáborné ${ }^{1}$}

\begin{abstract}
Absztrakt: $\mathrm{Az}$ Internet térnyerésével párhuzamosan megjelent az országhatárokon átnyúló online kereskedelem is. Ma már nem kell, hogy vevő és eladó ismerje egymást vagy lássa az értékesíteni kívánt terméket, az adásvételt az Interneten keresztül is meg lehet kötni. Az e-kereskedelem ma már egyre nagyobb szeletet hasít ki a világkereskedelemből. Ezzel azonban együtt jár a vásárlók nagyobb kockázata, az adófizetés esetleges elmaradása, a nem megfelelő minőségú, vagy az egészségre káros hatású termékek megvásárlásának lehetősége is. Ennélfogva az online kereskedelem területének szabályozása speciális követelmények elé állítja az országokat, kormányokat.
\end{abstract}

Kulcsszavak: Európai Unió, e-kereskedelem, online kereskedelem, ekereskedelem szabályozása

Abstract: The transnational online commerce turned up simultaneously with the transition of the internet into a widespread infrastructure. Nowadays a sale and purchase agreement can be concluded on the internet, the seller and the purchaser do not have to know each other or have to hold the product concerned. The e-commerce represents an increasing part of the worldwide trade, which is necessarily accompanied by the higher risks of the consumers, the possible avoidance of tax payment and the purchase of the products with insufficient quality or products which may cause adverse effect in health. As a consequence the counties, governments face with special requirements with regard to the regulation of the online trade.

1 Szegedi Tudományegyetem Állam- és Jogtudományi Kar, Doktori Iskola, PhD hallgató. E-mail címe: szucsne.aniko.h@gmail.com

A szerző további munkásságát lásd a Magyar Tudományos Művek Tára oldalán: https: / / m2.mtmt.hu/gui2/?type=authors\&mode=browse\&sel $=10047824$ 
Key words: European Union, e-commerce, online trade, regulation of the e-commerce

\section{BEVEZETÉS}

Napjainkban a világ minden részén - különös tekintettel a fejlett országokra - az e-kereskedelemből származó árbevétel és az így eladott árumennyiség soha nem látott mértékben bővül. Az online kereskedelem új kihívásokat jelent a kormányok és a jogi szabályozás szempontjából is, és az internetes kereskedelem ilyen mértékű és gyorsaságú fejlődésével a hazai és a nemzetközi szabályozás nem képes lépést tartani. A hagyományos kereskedelemhez képest az online kereskedelem szabályozása sokkal nehezebb és összetettebb, mivel az eladó és a vevő nem találkozik személyesen az ügylet kapcsán, ráadásul a terméket sem tudja a vásárló megfogni, kipróbálni, megnézni. Fogyasztóvédelmi szempontból is aggályokat vet fel az ügylet, hiszen a fogyasztó jogai is nehezebben érvényesíthetők, ami az Európai Unióban - ahol a fogyasztóvédelem erősítésére irányuló törekvések a kezdetektôl hangsúlyosan jelennek meg - kiemelt tagállami és uniós figyelmet eredményez. Különösen nehéz az országokat, integrációkat átívelő online kereskedelem szabályozása (megkockáztatom, hogy teljeskörűen talán lehetetlen is), hiszen ezek szabályozásához és ellenőrzéséhez számos ország kormányának az együttmúködése és közös szabályok alkalmazása volna célszerú. Az e-kereskedelem szabályozásával kapcsolatosan a legfontosabb hipotéziseim az alábbiak, amelyeket igyekszem a tanulmányomban megvilágítani:

- az online kereskedelem jóval nagyobb kockázattal jár a vásárlók számára, mint a hagyományos kereskedelem;

- mivel ez a típusú kereskedelem nem egy-egy országon belül zajlik, így jóval nehezebb annak szabályozása;

- véleményem szerint az országok, integrációk összefogása és a terület közös szabályozása jelenthetne valamelyest megoldást a problémákra (fogyasztók védelme, adók megfizetése ${ }^{3}$, biztonsági előírások betartása stb.).

Mivel a téma és a terület is túl nagy, így igyekszem az online kereskedelemmel kapcsolatos előnyöket és hátrányokat, valamint a

\footnotetext{
2 VÖRÖS, 2007

${ }^{3}$ A digitális adók kapcsán további szakirodalmat lásd: WÁGNER, 2020.
} 
szabályozás lehetőségét az Európai Unió (és ezen belül Magyarország) szemszögéből ismertetni.

\section{AZ ONLINE KERESKEDELEM TÉRHÓDÍTÁSA}

Az eNET Internetkutató és Tanácsadó Kft. (a továbbiakban rövidítve: eNET) kutatása alapján 2017-ben Magyarországon 27\%-kal nőtt az interneten keresztüli értékesítés forgalma a megelőző évhez képest, 2018ban pedig ez a növekedés $23 \%$ volt. A hagyományos kereskedelemből 2017-ben 6,2 \%-kal, 2018-ban pedig 7 \%-kal már az online kereskedelem részesedett. ${ }^{4} \mathrm{Ha}$ több évet nézünk, látható, hogy az ilyen típusú kereskedelem bővül, de a 2017 - 2018-as adatokból az is kitűnik, hogy a bővülés üteme kissé lassulni látszik. Az eNET előbb ismertetett kutatásából az is kiderült, hogy az egy online vásárlásra fordított összeg és az egy online vásárlóra jutó éves átlagos forgalom is egyaránt emelkedett. ${ }^{5}$ Egyre többen vásárolnak harmadik országbeli kereskedőktől is (nem Magyarországról és az uniós tagországokból), ami további problémákat vet fel szabályozási területen. „Globálisan az online kiskereskedelem forgalma négyszer gyorsabban bővül a hagyományos, offline kereskedelemnél, és évente közel egyötödével bővül majd a jövőben." "Ma már Magyarországon is egyre többen használják az internetes vásárlás és szolgáltatás igénybevételét, ráadásul az olcsósága miatt egyre több tranzakció keletkezik így Kínából vagy Ázsia a témában kevésbé szabályozott országaiból.

\section{AZ ONLINE KERESKEDELEMMEL KAPCSOLATOS ÁLTALÁNOS SZABÁLYOK}

Az online vásárlás a távollévő felek között megkötött szerződések közé tartozik, azaz a szerződéskötés során a kereskedő és a fogyasztó egyidejüleg nem tartózkodnak egy helyen, a szerződés megkötésére egymás jelenlétének hiányában kerül sor. A fogyasztó (azaz a vevő, vásárló) az eladó (avagy szolgáltató) által üzemeltetett internetes áruházban (webáruház)

\footnotetext{
${ }^{4}$ ENET, 2018. és ENET, 2019.

5 Az eNet kutatása alapján 2017-ben egy online vásárlás átlagos értéke 13400 forint volt, 2018-ban már 15400 forint. Az egy online vásárlóra jutó éves online forgalom 111 ezer forintról 124 ezer forintra nőtt.

${ }^{6}$ PIAC ÉS PROFIT, 2018.
} 
virtuális módon rendeli meg a kiválasztott terméket vagy szolgáltatást. Az uniós és a magyar jogszabályok is érvényesnek tekintik az ily módon létrejött szerződéseket, így ezekhez a szerződésekhez ugyanazok a jogi következmények kapcsolódnak, mint a hagyományos módon létrejött megállapodásokhoz.

\subsection{AZ ONLINE KERESKEDELEMBŐL SZÁRMAZÓ ELŐNYÖK ÉS HÁTRÁNYOK A FOGYASZTÓ SZEMSZÖGÉBŐL}

Az internetes vásárlásból - véleményem szerint - az alábbi előnyei származnak a vevőnek:

- időt és energiát spórol, hiszen nem kell utaznia az üzletig, otthonról vásárolhatja meg a kiválasztott árut;

- vásárláskor nem számít a földrajzi távolság, a mozgáskorlátozottság vagy a betegség;

- nem köti az üzlet nyitvatartási ideje, azaz nyitvatartási időre tekintet nélkül a nap 24 órájában vásárolhat a vevő;

- az internetes ajánlatok könnyedén összehasonlíthatók, így mód van a legolcsóbb vagy bármely más szempont alapján legmegfelelőbb ajánlat kiválasztására; valamint

- a kiszállítás megoldható, nincs szükség hozzá saját gépkocsira.

A távolról megkötött, interneten keresztül történő vásárlások azonban hátrányokkal, kockázatokkal is járnak a fogyasztó számára, amelyek többek között az alábbiak:

- kettős információs hiány:

- egyrészt a fogyasztó rendelkezésére kevés információ áll a termékről, nem tudja a terméket megfogni, megvizsgálni, felpróbálni, másrészről nem tud meggyőződni arról, hogy az áruról leírt információk ténylegesen megfelelnek-e a valóságnak;

- az is nehezen ellenőrizhetô, hogy a terméket kínáló kereskedő valóban létezik-e, illetve jogosult-e gazdasági tevékenység folytatására;

- reklamáció vagy szavatosság, jótállás érvényesítése esetén mennyire fog tudni eljárni, mennyire fogja tudni érvényesíteni a szerződésből eredő jogait, ráadásul legtöbbször azt sem tudja milyen jogszabályok, illetve melyik ország szabályozása szerint tud eljárni probléma esetén;

- bankkártyás fizetés esetén biztonsági kockázatok is felléphetnek; 
- nem biztos, hogy az internetes felületen található szerződési feltételeket pontosan érti, hiszen külföldi weboldalaknál sokszor nincs, rossz vagy éppen hibás a magyar nyelvű fordítás, illetve a feltételekben valamely jogszabályra történő hivatkozás esetén nem biztos, hogy a vevő az adott ország jogszabályát ismeri, illetve olvasni vagy helyesen értelmezni tudja;

- különösen aggályos lehet gyógyszerek, táplálékkiegészítők, valamint hasonló termékek vásárlása esetén, hogy azok összetevőit, gyártási feltételeit és hatóanyagait a vásárló nem tudja teljeskörūen megismerni.

\subsection{AZ ONLINE KERESKEDELEMRE VONATKOZÓ MAGYAR JOGSZABÁLYOK}

Az online kereskedelmet érintő szabályozásokkal több jogszabályban is találkozhatunk, amelyek közül a legfontosabbak a szolgáltatókra vonatkozó adatokkal és az elektronikus szerződéskötés lépéseivel kapcsolatosan az elektronikus kereskedelmi szolgáltatások, valamint az információs társadalommal összefüggő szolgáltatások egyes kérdéseiről szóló 2001. évi CVIII. törvény, valamint az elállási jog gyakorlásának részletes feltételeiről pedig a 2014. június 13-tól hatályos, a fogyasztó és vállalkozás közötti szerződések részletes szabályairól szóló 45/2014. (II.26.) Kormányrendelet. Természetesen az Interneten keresztül történő vásárlásokra is vonatkoznak továbbá a fogyasztóvédelemrôl szóló 1997. évi CLV. törvény és a Polgári Törvénykönyvről szóló 2013. évi V. törvény szabályai. ${ }^{7}$ Jól látható, hogy a szabályozás szerteágazó, több jogszabályt szükséges még Magyarországon is ismerni és alkalmazni, amely alapján egy esetleges probléma felmerülésekor a jogérvényesítés még egyetlen országon belüli elektronikus vásárlás esetén is problémát jelenthet, arról nem is szólva, ha külföldről rendeli meg a fogyasztó a terméket. Különös tekintettel arra, hogy ahogyan azt a Helsinki Bizottság is kiemelte jelentésében egy polgári eljárás során a rászorulóknak a pártfogó ügyvéd kirendelése kivételes és ebben nem egyedülálló hazánk Európában. ${ }^{8}$

\footnotetext{
7 INNOVÁCIÓS ÉS TECHNOLÓGIAI MINISZTÉRIUM, 2019.

${ }^{8}$ COUNTRY REPORTS, 2003.
} 


\subsection{ONLINE KERESKEDELEM - EGYSÉGES UNIÓS SZABÁLYOK}

Az Európai Unió területén a 2000/31/EK - elektronikus kereskedelem az EU-ban címú irányelv szabályozza az online kereskedelmet. Az irányelv célja az elektronikus kereskedelemmel kapcsolatos különböző kérdésekre vonatkozó egységes uniós szabályok létre hozása. Az irányelv többek között - kiterjed az alábbiakra: hírportálok, termékek és szolgáltatások értékesítése, szakmai szolgáltatások (mint orvosi-, egészségügyi, ügyvédi stb. szolgáltatások), közvetítői szolgáltatások, stb.

„Az irányelv létrehozza azt az elvet, amely szerint e szolgáltatások üzemeltetőire a - szolgáltatások elindításával és nyújtásával kapcsolatos szabályozások kizárólag a bejegyzett székhelyük szerinti uniós országban vonatkoznak, és nem abban az országban, ahol az általuk használt szerverek, e-mail címek vagy online postafiókok találhatók." Ez alapján az ilyen tevékenységet folytatókra az ,anyaországban” meglévő szabályozás vonatkozik, ugyanakkor ezeket a szabályokat nem minden vásárló (például külföldi vásárlók) ismeri. A nemzeti kormányoknak a hazai szintú szabályozásban biztosítaniuk kell, hogy az internetes vásárlásokat lehetôvé tevő üzemeltetők - tartós és könnyen hozzáférhető formában - közzé tegyék a tevékenységükkel kapcsolatos alapvető információkat (nevüket, címüket, cégjegyzékszámukat, elérhetőségüket, szállítási feltételeiket stb.) a vásárlási oldalon. Ez azonban nem feltétlenül jelenti azt, hogy a vásárló ezen információk alapján - szükség esetén - el is éri őket (akkor még nem is szólva a nyelvi nehézségekről, hogy milyen nyelven és hogyan érteti meg magát egy-egy probléma kezelése során, mert sokszor a megadott nyelven csak időszakosan vagy „külsős” munkatárs segítségével lehet kommunikálni).

Az irányelv alapján az elektronikus úton megkötött szerződéseknek minden uniós országban a papíralapú szerződésekkel egyenrangú jogi státuszt kell biztosítani. Pontosan meg kell adni, hogy milyen lépésekkel tudják a vásárlók véglegesíteni a vásárlásukat, hogy mely nyelveken tudnak vásárolni és ügyet intézni, valamin a megkötött szerződést később is meg tudják-e tekinteni. További követelmény, hogy a fogyasztó menteni és nyomtatni tudja az ily módon létrejött szerződést. Minden online vásárlási felületen meg kell jeleníteni az „ÁSZF-et” is (Általános Szerződési Feltételek).

${ }^{9}$ EUR-LEX, 2019. 
Természetesen a 2011/83/EU irányelv a fogyasztói jogokról szintén vonatkozik az internetes felületen megkötött szerződésekre is. „Ezen irányelv a távollevők között és az üzlethelyiségen kívül kötött szerződésekkel, valamint az ezektől eltérő szerződésekkel kapcsolatban nyújtandó tájékoztatásra vonatkozó szabályokat állapít meg. Az irányelv emellett szabályozza az elállási jogot a távollevők között és az üzlethelyiségen kívül kötött szerződések esetében, és összehangol néhány, az üzleti vállalkozások fogyasztókkal kötött szerződései teljesítésével és egyéb szempontjaival foglalkozó előírást." 10

Az irányelv 4. bekezdése kimondja, hogy a távollevők között kötött fogyasztói szerződések egyes vonatkozásainak harmonizációjára van szükség, mert az előmozdíthatja az olyan valódi fogyasztói belső piac kialakítását, amely képes megfelelő egyensúlyt teremteni a fogyasztóvédelem magas szintje és a vállalkozások versenyképessége között, a szubszidiaritás elvének tiszteletben tartása mellett. Ezen a területen is fontos, hogy uniós állampolgárok és vállalkozások ugyanolyan szabályozás, előírás mentén végezhessék tevékenységüket, mint az adott ország saját állampolgárai és vállalkozásai. Ugyanis az egyes országok szabályozásában meglévő különbségek a kereskedôket és a vásárlókat érintő jelentős belső piaci akadályokat jelentenek, márpedig az uniós országok egyik fó célja a teljes belsô piac kialakítása, a kereskedelemben található korlátozó tényezôk megszüntetése, a szabadpiaci verseny kialakítása, a diszkrimináció minden formájának eltörlése. ${ }^{11} \mathrm{Ha}$ valamely ország valamely szabálya miatt egy kereskedőnek többletköltsége keletkezik, akkor az versenyhátrányt szenved, az pedig ellenkezik az unió alapelveivel. Ha a tagországok szabályozása miatt jelentős széttagoltság jön létre, az a fogyasztók belsô piacba vetett bizalmát is megrendíti. A szabályozás harmonizációja viszont mind a kereskedők, mind pedig a fogyasztók bizalmát erôsíti, és olyan jogbiztonságot teremt, ami szükséges a piac megfelelő múködéséhez. Az uniós jognak megfelelően továbbra is tagállami hatáskör marad ezen irányelv implementálásának módja, valamint esetlegesen rendelkezéseinek az irányelv hatályán kívül esô területekre történő alkalmazása. „A tagállamok tehát fenntarthatnak vagy bevezethetnek az ezen irányelv hatálya alá nem tartozó szerződésekre vonatkozóan az ezen irányelv rendelkezéseinek vagy egyes rendelkezéseinek megfelelő nemzeti jogszabályokat." ${ }^{12}$ Mivel ez az irányelv csak a

\footnotetext{
${ }^{10}$ EUR-LEX, 2019.

${ }^{11}$ KIRÁLY, 2004.

${ }^{12}$ EUR-LEX, 2019.
} 
magánszemélyre, mint fogyasztóra vonatkozik, a tagállamok határozhatnak úgy is, hogy az ezen irányelvben foglalt szabályok alkalmazását kiterjesztik jogi személyekre vagy olyan természetes személyekre, akik ezen irányelv értelmében nem fogyasztók, mint amilyenek a nem kormányzati szervezetek, az induló vállalkozások vagy a kis- és középvállalkozások (de bevezethetik az irányelvet változatlan formában is). Ezen a területen a tagállamoknak nagy a szabadsága, így az intézményi online vásárlók elég nagy különbségeket észlelhetnek az unión belül is a szabályozásnak ezen a területén.

Az uniós szabályozásnál szükséges még megemlíteni az Európai Parlament és a Tanács 2018/302 számú rendeletét, mely a belső piacon belül a vevő állampolgársága, lakóhelye vagy letelepedési helye alapján történő indokolatlan területi alapú tartalomkorlátozással és a megkülönböztetés egyéb formáival szembeni fellépésről szól. ${ }^{13}$ A rendelet több olyan problémát kezelt, amelyek a belsô piaccal nem fértek össze. Kiemelendő, hogy a rendelet szerint a kereskedô nem korlátozhatja semmilyen formában vagy mértékben egy vevő hozzáférését az online felületéhez állampolgársági, lakóhelyi vagy letelepedési alapon, továbbá megrendelhessen bármilyen terméket szolgáltatást. Nem szükséges tehát minden tagállamba vállalnia a szállítást, de ha az általa megjelölt földrajzi területre más tagállamból kér szállítást a vevő és vállalja, hogy ott az árut ő vagy egy általa kijelölt személy átveszi, akkor a kereskedő a kiszállítást köteles a megadott címre végrehajtani. ${ }^{14}$ Szintén egy gyakorlati korlátozást törölt el a rendelet azzal, hogy kötelezte a kereskedőket a más tagállamban kiállított bankkártya elfogadására - feltéve hogy elfogad bankkártyás fizetést, hiszen itt sem az adott fizetési mód elfogadására kötelez a szabályozás, csak a megkülönböztetés tilalmát érvényesíti. ${ }^{15}$

\subsection{DigITÁLIS EGYSÉGES PIAC EURÓPÁBAN}

Az egységes digitális piac létrejöttével a felhasználók egyenlő hozzáféréssel rendelkeznének a termékekhez és szolgáltatásokhoz, minden uniós polgár, vállalat és kormány bizalommal használhatja az online szolgáltatásokat és élvezheti a digitális forradalom előnyeit. Miért is van

\footnotetext{
${ }^{13}$ EUR-LEX, 2019.

${ }^{14}$ NAGY, 2018.

15 PWC LEGAL, 2019.
} 
szükség a digitális egységes piacra? Mert az Európai Unió lakosságának mindössze 59 \%-a rendelkezik 4G gyorsaságú Internet hozzáféréssel, pedig megfelelő Internet hozzáféréssel a fogyasztók több milliárd eurót tudnának megtakarítani online vásárlással. A határokon átívelő vásárlások több mint fele valamilyen akadályokba ütközik, pedig a kisvállalkozások a nemzeti jogszabályok uniós harmonizálásával csak a jogi és fordítási díjakon is 9000 eurót tudnának piaconként megspórolni. ${ }^{16} \mathrm{Az}$ Európai Unió célja az áruk és szolgáltatások egységes piacának létrehozása a tagállamok teljes területén, a digitális egységes piac megvalósításának keretében a szabályozási akadályok lebontásával (és uniós szintű szabályozással) ugyanezt célozza meg digitális (online) téren. A digitális egységes piacba beletartozik az online kereskedelem, a telekommunikáció és a digitális marketing. Az Európai Bizottság 2015-től ütemtervet hozott létre a digitális egységes piac létrehozásának elősegítésére. Ebben konkrétan megfogalmazták azokat az intézkedéseket, amelyeket meg kell hozni a digitális egységes piac megteremtéséhez. Az európai digitális egységes piaci stratégiának része a személyes adatok védelmére vonatkozó szigorú új szabályok megalkotása, a roaming díjak eltörlése, a kiberbiztonsági stratégia felülvizsgálata, az online platformok és a vállalkozások közötti kapcsolatokat aláásó tisztességtelen szerződéses feltételekkel és kereskedelmi módszerekkel szembeni fellépés, a WiFi4EU kezdeményezés (,a WiFi4EU kezdeményezés Unió-szerte támogatja az ingyenes wifi-hotspotok létrehozását a helyi közösségekben, úgymint köztereken, parkokban, kórházakban és más nyilvános helyeken") ${ }^{17}$, valamint az uniós szerződési jog modernizációja. Ezekből már vannak olyan részek, amelyek megvalósultak, és vannak, amelyeknek a megvalósítása még napjainkban is zajlik.

\subsection{AZ ONLINE KÖZVETÍTŐ SZOLGÁLTATÁSOK SZABÁLYOZÁSA (2020. JÚLIUS 12-TŐL HATÁLYOS)}

A digitális technológiák térnyerése és fejlődése, különösen a nagy területekre kiterjedő és nagy létszámú ügyfelet elérő, illetve nagy profitra szert tevő online közvetítő szolgáltatások megjelenése és fejlődése az uniót is rákényszerítette a szabályozás átgondolására. Az EU 2019/1150 rendelete

\footnotetext{
16 Az adatok a https://op.europa.eu/webpub/com/factsheets/digital/hu/ oldalról származnak.

${ }^{17}$ Forrás: https://op.europa.eu/webpub/com/factsheets/digital/hu/
} 
(2019. június 20.) az online közvetítő szolgáltatások üzleti felhasználói tekintetében alkalmazandó tisztességes és átlátható feltételek előmozdításáról szól. A rendelet 7-es pontja kimondja, hogy „,a belső piacon belüli tisztességes, kiszámítható, fenntartható és megbízható online üzleti környezet biztosítása érdekében célszerú uniós szinten célzott, kötelező szabályokat megállapítani. A rendelet célját miszerint a tisztességes, kiszámítható, fenntartható és megbízható online üzleti környezet belső piacon belüli biztosítását a tagállamok nem tudják kielégitóen megvalósítani, az Unió szintjén viszont a terjedelme és hatásai miatt ez hatékonyabban megvalósítható, ezért az Unió intézkedéseket hozhat az Európai Unióról szóló szerződés 5 . cikkében foglalt szubszidiaritás elvének megfelelően. A rendelet szabályai megfelelnek az arányosság elvének. Az online közvetító szolgáltatások üzleti felhasználói számára kell Unió-szerte megfelelő átláthatóságot és hatékony jogorvoslati lehetôségeket biztosítani, egyrészt az Unión belüli, határokon átnyúló üzleti tevékenység megkönnyítése érdekében, így törekedve a belső piac megfelelőbb múködésére." Online közvetítő szolgáltatást nyújtóknak számítanak például az Internet hozzáférést és egyéb internetet szolgáltatók, az adatfeldolgozó és keresőmotorok, az e-kereskedelem szolgáltatók (amelyek nem a saját termékeiket értékesítik), az online fizetési felületek és az online tartalomszolgáltatók, közösségi médiaszolgáltatók (nem saját maguk szerkesztik a hozzáférhetôvé tett tartalmakat vagy tulajdonolják ezek szerzői jogait). A rendelet igyekszik az online szolgáltatásokra vonatkoztatható teljes szabályozási terület lefedésére (például szerződési feltételek, szerződés semmissége, adatvédelem, szellemi tulajdonhoz füződő jogok védelme, jogorvoslat lehetősége), de oly módon, hogy ne kösse „gúzsba" a területből adódó innovatív és kreatív elmét és gyakorlatot ${ }^{18}$. A rendelet 8 -as pontja kifejti: „a rendelet nem érintheti a nemzeti polgári jogot, feltéve, hogy a nemzeti polgári jogi szabályok összhangban vannak az uniós joggal, és amennyiben az érintett szempontokat e rendelet nem szabályozza. A tagállamok továbbra is szabadon alkalmazhatják azokat a nemzeti jogszabályokat, amelyek tiltják vagy szankcionálják az egyoldalú magatartást vagy a tisztességtelen üzleti gyakorlatokat, amennyiben az érintett szempontokat e rendelet nem szabályozza." A jogorvoslati lehetőségeknek alapjául az online közvetítők panaszkezelési rendszerét tekinti. Az online közvetítők számára a rendelet

\footnotetext{
$18 \mathrm{Az}$ adatvédelmi szabályozás a digitális gazdaság egyik fontos pillére, amelyet az Európai Unió az elmúlt években úttörő módon igyekezett fejleszteni, elegendő a GDPR bevezetésére gondolni. AZ uniós adatvédelemről bővebben lásd LABANCZ, 2020.
} 
által előírt belső panaszkezelési rendszernek az átláthatóság és az egyenértékű helyzetek egyenlő módon történő kezelésének elvén kell alapulnia. Gyakorlatilag a panaszkezelési rendszer célja annak biztosítása, hogy a panaszok jelentős hányadát egymás között, észszerű időn belül megoldhassa az online közvetítő szolgáltató és az érintett felhasználó. Az online közvetítők és az üzleti felhasználók közötti viták rendezésére a rendelet előírja, hogy minden közvetítőnek ki kell választaniuk legalább két olyan, köz- vagy magán közvetítőt, akikkel készek együttmüködni a vitás kérdések rendezése érdekében, hogy a hosszú bírósági procedúrát meg lehessen előzni. Csakolyan közvetítőt lehet választani, amely semlegesnek számít. Az ilyen közvetítőknek számos feltételnek kell megfelelniük: például valamely tagállam jogának megfelelően kell őket létrehozni, nonprofit jellegűnek kell lenniük és fenntartható alapon kell céljaik elérésén dolgozniuk. „A szolgáltatásaikat az Unión kívülrôl nyújtó közvetítők csupán akkor jelölhetők meg, ha biztosított, hogy szolgáltatásuk igénybevétele semmilyen módon nem csorbítja az érintett üzleti felhasználóknak az uniós jog vagy a tagállami jogok által kínált jogvédelmét, ideértve e rendelet követelményeit, valamint a személyes adatok és az üzleti titkok védelmére vonatkozó jogot." 19 A rendelet nem tiltja meg a bírósági jogorvoslati lehetőséget, de ezek hatékonyságát rengeteg dolog befolyásolhatja. Ilyen lehet, hogy valamelyik fél számára korlátozottan állnak rendelkezésre a pénzügyi eszközök vagy fél a megtorlástól, de ezt a lehetőséget, illetve ennek hatékonyságát a szerződési feltételekben szereplő, kizárólagosan alkalmazandó jogot és vitarendezési fórumot meghatározó rendelkezések is befolyásolhatják. A rendeletet nem lehet alkalmazni az olyan online fizetési szolgáltatásokra, online reklámeszközökre vagy online hirdetési piacterekre, amelyeket nem azzal a céllal biztosítanak, hogy előmozdítsák a közvetlen ügyletek kezdeményezését, és amelyek nem foglalnak magukban fogyasztókkal fennálló szerződéses jogviszonyt. A rendelet nem érinti azokat a nemzeti szabályokat, amelyek az uniós jognak megfelelően tiltják vagy szankcionálják az egyoldalú magatartást vagy a tisztességtelen kereskedelmi gyakorlatokat, ha az érintett szempontokat e rendelet nem szabályozza.

\section{AZ ONLINE VÁSÁRLÁSOK KOCKÁZATAI A SZABÁLYOZÁSOK TÜKRÉBEN}

${ }^{19}$ EU 2019/1150 rendelete 40. pont 
A legfontosabb hátrányai (vagy szabályozatlanságai) az online kereskedésnek meglátásom szerint az alábbiak:

- Ugyan a 2011/83/EU irányelv és a hazai jogszabály ${ }^{20}$ is kimondja, hogy a kereskedőnek tartós adathordozón kell tárolnia az online ügylettel kapcsolatos információkat (szerződés, kiszállítás, átvétel, esetleges reklamáció stb.) és a tartós adathordozóknak lehetôvé kell tenniük a fogyasztó számára az adattárolást mindaddig, amíg a fogyasztó ezt a kereskedővel való kapcsolatából származó érdekei védelmének érdekében szükségesnek tartja. A tapasztalataim alapján ez az egyik legköltségesebb és legkevésbé megvalósítható előírás. Egyrészt nem határozható meg pontosan, hogy meddig tart a fogyasztó „érdekeinek védelme”, másrészt nincs olyan adathordozó, ami ne sérülne meg évek alatt, vagy ne kapna vírust stb. A külső tárhely szolgáltatások ára pedig olyan borsos, hogy a kisebb forgalmú kereskedők képtelenek évek alatt is kitermelni, az általános adatvédelmi rendeletben foglaltak betartásának nehézségeit nem is említve. $^{21}$ Így ezt a jogszabályt nehéz betartani, betartatni és megfelelően ellenőrizni is.

- Az áru kiszállítása általában pénzbe kerül, de ha átvételkor kiderül, hogy mégsem megfelelő a rendelt áru, akkor a fogyasztó (rendszerint) csak a saját költségén tudja a vásárolt terméket visszajuttatni az eladónak. Így már két szállítást is kifizetett, melynek költsége ôt terheli és az általa kiadott összeget senki nem téríti meg számára. Sok webáruház magas szállítási költséget számít fel, ezért érdemes lenne a fogyasztóvédelmi hatóságoknak rendszeresen megvizsgálni, hogy a valós költségeiket meghaladja-e, hiszen, ha bevételre és nyereségre tudnak szert tenni a vállalkozások pusztán nem megfelelő termék postázásával is, akkor az sérti a fogyasztók érdekeit. A visszaküldött áru ellenértéke továbbá sokszor csak hetek múlva kerül visszautalásra a vevőnek, aki a fogyasztó ismét veszteséget (elmaradt kamat) kénytelen elkönyvelni.

- Versenyhátrányba kerülnek a hazai termelők, gyártók, hiszen az olcsó (sokszor ráadásul gyenge minőségû) ázsiai termékekkel nem tudják felvenni a harcot, főként, hogy nekik az itthon eladott

20 2001. évi CVIII. törvény az információs társadalommal összefüggő szolgáltatások egyes kérdéseiről és az 1/2018. (VI.29.) ITM rendelet a digitális archiválás szabályairól 21 Az EuRópai Parlament És A TANÁCs 2016/679 RENDELETE 
termékek után még az adókat és egyéb költségeket is meg kell fizetniük, miközben a külföldi internetes kereskedők sok esetben erősen adót optimalizálnak.

- Mivel fogyasztónak csak a magánszemélyek számítanak, így az egyéni vállalkozók, társas vállalkozások, egyéb szervezetek sokkal nehezebben tudják érvényesíteni a téves vagy rossz minôségū termékekből, szolgáltatásokból eredő követeléseiket a kereskedőkkel szemben.

- Míg az üzlettel rendelkező kereskedőket az adóhivatal, az élelmiszer ellenőrző hivatal stb. sokszor ellenőrzi, addig az online megrendelhető termékek sokszor semmilyen minőség ellenőrzésen nem mennek át. Különösen aggályos ez élelmiszerek, gyógyszerek és gyermekek számára vásárolt termékek esetén. Az erre vonatkozó szabályok, előírások ellenőrzése lehetetlen, hiszen sokszor azt sem lehet tudni, hogy az adott webáruház melyik országban található raktárból szállít.

- Az internetes felületen - fizetés céljából - megadott bankkártya adatok rossz kezekbe is kerülhetnek, amelyek igen súlyos problémákat okozhatnak.

- A reklamáció, csere, garancia érvényesítése még hazai online vásárlás esetén is nehézkes, sokszor hetekig - hónapokig tartó levelezés, telefonálás után lehet a pénzünket visszakapni. Más országból történő rendelés esetén pedig majdnem lehetetlen. Főleg kisebb összeg esetén annyiba kerül a termék visszaküldése, levelezés, telefonálás, hogy a vásárló nem is próbálkozik vele. Sajnos, véleményem szerint sok eladó pontosan erre is számít.

- Sokkal nehezebb ellenőrizni is az online kereskedelmet (mennyi például egy internetes szolgáltató előfizetői száma, amely után jogdíjat kellene fizetni), így az államok jelentős adóbevételtől esnek el, a hazai piacon nem online kereskedők pedig versenyhátrányba kerülnek.

A fentiek előfordulása esetén a vevő természetesen élhet a saját országa jogszabályai által meghatározott igényérvényesítési lehetőséggel, de határokon átnyúló kereskedelem esetén ez általában nem vezet eredményre. Ha ez az út nem járható és a fogyasztó kimerítette saját országának jogorvoslati lehetőségeit és ügye nem vezetett eredményre, akkor fordulhat az Európai Fogyasztói Központhoz (a továbbiakban EFK). „Az EFK-t elsődleges és legfontosabb feladata a határon átnyúló (amikor a fogyasztó 
lakóhelye és a kereskedő székhelye különböző országban, de valamelyik uniós tagállamban, Izlandon vagy Norvégiában található) egyedi fogyasztói panaszok rendezésében való ingyenes érdemi, hatósági eljáráson kívül történő közreműködés és segítségnyújtás. ${ }^{22}$ " A segítséget az ügyben érintett fél országában található társszervezete útján nyújtja, célja a panasz békés megoldásának elősegítése, a drága és hosszadalmas bírósági pereskedés elkerülése. Az Európai Fogyasztói Központ alapvetôen a fogyasztókat képviseli, de - igény esetén- a vállalkozások számára is lehetőség ad egy vitás ügy peren kívüli rendezésére.

\section{KONKLÚZIÓ}

Tanulmányom elején az volt a hipotézisem, hogy az online kereskedelem jóval több kockázattal jár a vásárlók számára, mint a hagyományos kereskedelem. Azt hiszem ez a fentiek alapján igaznak bizonyult. Azt is feltételeztem, hogy ennek szabályozása jóval nehezebb, mint a hagyományos, bolti kereskedelem szabályozása. Ennek az egyik legkézzelfoghatóbb oka a távolság (vevő és eladó között), illetve a jelentős számú nemzetközi elem a tranzakciók során. Az e-kereskedelemmel kapcsolatos problémákat egy ország egyedül soha nem fogja tudni megoldani, mivel a rendszer és a probléma is globálisan jelentkezik. Az online kereskedelem volumenben és értékben is óriási ütemben bővül, így valamit kezdeni kellene a globális szabályozás lehetőségével. Minél több országnak kellene felismernie az ebben rejlő lehetőségeket és veszélyeket, és össze kellene fogniuk egy olyan nemzetközi szabályozás érdekében, amelynek betartására és betartatására mindenkinek nagy figyelmet kellene szentelnie. Talán egy nemzetközi szervezet felállítása sem ártana, amely a globálisan meghozott szabályokat ellenőrizné. Az adózás, adófizetés kérdése a leginkább érdekes „dolog” az országok számára. Az online kereskedelem esetén ugyanis nem a fogyasztó országában keletkezik adófizetési kötelezettség (vagy ha igen, az szinte behajthatatlan, mert maga a kereskedelem is „láthatatlan” és nehezen ellenőrizhető). Mivel költségeinek fedezésére, a lakosság életszínvonalának stb. emelésére csak az az ország kormánya képes, amely tud adókat beszedni, így érdemes foglalkozni egy olyan rendszer felállításával, amelyben ez a terület jobban ellenőrizhetôbb és szabályozhatóbb lesz. Ha ezt sikerülne globális szinten elérni, akkor a

22 Innovációs és Technológiai Minisztérium, 2019. 
vásárlók kockázatai is csökkennének. Ekkor talán biztonságos mederben lehetne tartani ezt a folyamatot, de sajnos erre napjainkban nem sok esélyt látok, bár egyes régiók és integrációk között vannak erre irányuló megnyilvánulások, kezdeményezések.

\section{FELHASZNÁLT IRODALOM}

Az EuRÓPAi PARLAMENT ÉS A TANÁCS 2016. ÁPRILIS 27-EI 2016/679 RENDELETE a természetes személyeknek a személyes adatok kezelése tekintetében történő védelméről és az ilyen adatok szabad áramlásáról, valamint a 95/46/EK rendelet hatályon kívül helyezéséről (általános adatvédelmi rendelet)

AZ EuRÓPAi PARLAMENT ÉS A TANÁCS (EU) 2019/1150 RENDELETE (2019. június 20.) az online közvetítő szolgáltatások üzleti felhasználói tekintetében alkalmazandó tisztességes és átlátható feltételek előmozdításáról

Country Reports of the Helsinki Foundation (2003): Access to justice in Central and Eastern Europe, Hungary, Public Interest Law Initiative, 210

DÖMÖTÖRFY BORBÁLA - FIRNIKSZ JUdiT - MEZEI PÉTER (2019): Miért lett tilos a ,geo-blocking"? Elérhető:

https://www.retivarszegipartners.hu/miert-lett-tilos-a-geo-blocking/ (Letöltve: 2019. október 30.)

ENET (2018) Elérhető: https://enet.hu/hirek/tiz-ev-alatt-tizszeresere-notta-magyar-e-kiskereskedelem/ (Letöltve: 2019. október 12.)

ENET (2019) Elérhető: https://enet.hu/hirek/tobb-mint-1000-milliardforintot-koltenek-el-magyarorszagon-az-e-kiskereskedelemben/ (Letöltve: 2019. október 26.)

EUR-LEX (2019) Elérhető: https://eur-lex.europa.eu/legalcontent/HU/TXT/?uri=LEGISSUM\%3Al24204 (Letöltve: 2019. október 15.)

EUR-LEX (2019) Elérhető: https://eur-lex.europa.eu/legalcontent/HU/TXT/?uri=celex\%3A32011L0083 (Letöltve: 2019. október 15.)

EUR-LEX (2019) Elérhető: https://eur-lex.europa.eu/legalcontent/HU/TXT/?uri=celex\%3A32011L0083 (Letöltve: 2019. október 15.)

EUR-LEX (2019) Elérhető: https://eur-lex.europa.eu/content/news/geo- 
blocking-regulation-enters-into-force.html?locale=hu (Letöltve: 2019. október 30.)

INNOVÁCIÓS ÉS TECHNOLÓGIAI MINISZTÉRIUM (2019) Elérhető. http:// fogyasztovedelem.kormany.hu/node/20 (Letöltve: 2019. október 20.)

INNOVÁCIÓS ÉS TECHNOLÓGIAI MINISZTÉRIUM (2019) Elérhető: http://fogyasztovedelem.kormany.hu/node/35641 (Letöltve: 2019. október 28.)

KIRÁLY MiKLós (2004), Az Európai Közösség Kereskedelmi Joga, Budapest, KJK-KERSZÖV

Labancz Andrea (2020): Az adatvédelmi jog és a személyes adatok múltja, jelene és jövője az uniós szabályozásban, Külügyi Múhely, 2020/1. szám. Elérhető: DOI azonosító: https://doi.org/10.36817/km.2020.1.3

NAGY SÁNDOR (2018): Szakmai összefoglaló kereskedők számára az EU 2018/302. sz. („GEO-Blocking” rendeletéről), Ecommerce Hungary Elérhetô: https://ecommerce.hu/a-geo-blocking-rendelet-ertelmezese/ (Letöltve: 2019. október 30.)

PIAC ÉS PROFIT (2018): Egy dolog biztos: van jövő az online kereskedelemben Elérhető: https://piacesprofit.hu/kkv cegblog/egydolog-biztos-van-jovo-az-online-kereskedelemben/ (Letöltve: 2019. október 12.)

VÖRÖS JUDIT (2007): Tisztességtelen verseny - fogyasztóvédelem, Budapest, MTA Jogtudományi Intézet, 16

WÁGNER TAMÁs ZOLTÁN (2020): Digitális adók kérdése, különös tekintettel a cseh szabályozásra, Külügyi Műhely, 2020/1. szám. DOI azonosító: https://doi.org/10.36817/km.2020.1.6 